\title{
Social worker involvement in identifying problems and needs of families with mentally ill members
}

\author{
N. Kovalčíková and K. Letovancová \\ Trnava University in Trnava, Trnava, Slovakia
}

\begin{abstract}
The aim of the current study was to explore the impact of schizophrenia on the life of the patient and his family, in particular, which problems people with schizophrenia and their families face. We applied a qualitative research strategy and method of semi-structured interview. Qualitative analysis of the data demonstrated barriers in the working and financial areas of life of people with schizophrenia. In addition, schizophrenia negatively affects social interactions of patients which lead to their social isolation which is also derived from barriers at work. Families with this kind of patient suffer mainly in the economic sphere of life with the necessity to leave the job and take care of an ill member. These families also suffer from isolation, restriction of social contacts, reduction of freetime activities, and many other problems included within the barriers in social interactions. Family members suffer psychological stress and they badly cope with the situation if the ill member is hospitalized. In addition, the family meets with the structural discrimination in the form of lack of information about the disease, lack of day care centres network and similar barriers in communication with physicians and the other professionals.
\end{abstract}

\section{Introduction}

Schizophrenia is one of the hardest and most serious mental illnesses because it destroys not only the intellectual and personal life of a person, but an emotional and social part of it, too [1] Schizophrenia is a troublesome state that seriously disrupts life of not just the person suffering from it, but also lives of their relatives and friends [2] Almost 1\% of population suffers from schizophrenia. In Slovakia it comprises about 50 thousand people suffering from this disease [3]. The term Schizophrenia is derived from the Greek words "schizo" (split) and "phren" (mind) and its meaning is "split mind" [4]. It is a chronic disease that has four stages and has a great impact on a human being: it causes the lack of energy and social withdrawal that stops majority of patients from living normal life again. It is sometimes caused by misunderstanding and prejudices from their society, too [5]. The treatment comes from the current view of schizophrenia as a life-long disease accompanied by persistent symptoms and occasional relapses in majority of cases. For these reasons the medication of schizophrenia has to be complex, individualized and measurable [6]. Complex treatment of schizophrenia includes medication that is called also pharmacotherapy, electrotherapy, psychotherapy, and psychiatric rehabilitation. [7]. In the system of support, social work has an important role. According to Matouška [8], the sense of a social work is to reveal, explain and solve social problems of the clients. According to Nováková [8] social work has a long-lasting tradition in psychiatry and is applied to both an inpatient and outpatient care. Social worker is an inseparable member of the team of doctors. He takes part in main 
visits, consultations, and community meetings of patients. His job includes social assistance and law counselling, a patient's re-socialization, cooperation with their family and with other experts and institutions. Clients who undergo treatment of psychotic disease are in a very problematic social situation and need help from a social worker. The anamnesis interview plays an important role at the beginning of the treatment. Within the diagnosis the social worker has a conversation with a client which is aimed at getting information about their job, living conditions, family and social problems that cause mental illness. It is very important to cooperate with a patient who has repeatedly undergone hospitalizations, because it can significantly change his social situation. A social worker gets information from the family and in this way he helps the patient's family members, too. If a client has a dependent child but nobody who can take care of him/her, the social worker cooperates with the Department of Child Protection and Social Curatorship in order to put the child into temporary alternative care. He also arranges an early exposure of necessary medical documentation which is important for the patient to receive their disability pension. In order to set an effective intervention it is necessary to do the scrupulous anamnesis activity which results into a social diagnose and understanding of the needs and problems of the client and their family. In the process of diagnostics we should be able to reveal not just the important facts, but also their casual connections and we should set their relevance in relation to the particular situation [9].

Based on aforementioned, we aimed our research at the study of an impact of schizophrenia on the life of a person and their family, as well as at revealing the most common problems that people suffering from schizophrenia have to face. As Levická [10] claims, an efficiency of help given to these people depends upon the social worker's ability to correctly identify the client's problem situations. An understanding of its development/dynamics and subsequent planning of the possible intervention is also very important.

\section{Methodology and participants}

In order to achieve the main research objective we have chosen a qualitative research strategy. In terms of the qualitative research method we used a semi-structured dialogue as a basic technique of data collection. Studies of the people suffering from schizophrenia were carried out in the Take-care centre in Trenčín. Participants of the research were the clients of the Daily Care Centre. There were 6 people asked for an interview, but just 3 of them agreed. Individual interviews lasted for about 50 minutes.

Research, as set by the objectives, was applied also to the family members of the people suffering from the disease. This part of the research was carried out right in the people's homes, whereas the dialogues were held at places in which participants were not disturbed. In this case we got three patients who agreed to participate in the research. Dialogues with them lasted 45 minutes in average. Participants of our research were chosen by a non-random, purposeful selection. We did the selection based on the preset criteria. That ensured us to choose participants of our research who share similar denominators.

There were 6 participants in our research, whereas 3 of them belonged to the sample 1 and 3 others to sample 2. Participants of sample 2 were only women, because those are mostly women who take care of people suffering from schizophrenia. Sample 1 consisted of one woman and two men; their average age was 37, 6 years. Two of them were single and one was married. All the participants had graduated from a university. From the viewpoint of their active labour market status, two of them were receiving disability pension and one was working in Sheltered Workshop. The third participant was unemployed. The participants have been suffering from schizophrenia for 7 years in average. 
The research sample 2 consisted of three women whose age was 45 years in average. Two of them were single; one was married. Two women were the patients'mothers; the third one was a patient's sister. Being non-professional caregivers, two of them were receiving a caregiver financial assistance and one of them had a job.

Dialogues were recorded on Dictaphone and then rewritten as texts. Transcripts of the dialogues were then analyzed. Within the analysis we used an inductive approach of creating categories and based on them, we specified problems occurring in life of people suffering from schizophrenia, as well as of their family members.

\section{Results}

\section{Interpretation of research results: Research sample No. 1}

The first category deals with health barriers. As mentioned above, schizophrenia is one of the most serious mental illnesses. Therefore it is natural that it has a serious impact on a person. Our participants mentioned most often the limitations in form of disease symptoms. Symptoms of schizophrenia are: formal thought disorder, content thought disorder, emotive disorder, disorders of perception and personality disorders. They are the crucial reasons of changes in the life of a person suffering from schizophrenia. Participants in their dialogues mentioned how the symptoms change their lifestyle. Everything in their lives has been adapted to the illness. Schizophrenia is such a serious illness that it needs a long-term hospitalization that can last for several months. The same happened in lives of our participants. They also mentioned the negative effects of treatment which makes the person feel completely different from what they felt before the outbreak of the illness. They also mentioned fighting with many different undesirable symptoms of medication. Práznovská [11] claims that the side effects of the treatment may become a reason for separation of a person from the community. It is a painful moment for a person suffering from schizophrenia because there is usually no change in their intelligence at all.

The second category deals with employment barriers. In this area there was a research conducted by Dóci [12], who came to the result that 73, 74\% of 99 patients suffering from schizophrenia received disability pension and 92 of them were not working at all. The research revealed the need of financial and material help from the family, too. Also the fact that employers do not want to employ people suffering from mental illness, was revealed.

The samept results were proved in our research. Since it was a quantitative research, thanks to this research method and the choice of participants, we studied the problem in more details. We found out several causes and consequences of invalidity mentioned above. As to the choice of participants, we want to stress that we carried out the research with people visiting Take-care centre. These people are more integrated into everyday life than patients undergoing a long-lasting hospitalization. Our participants hardly bear the loss of job. Despite the attempts to work they have not found a job and it was difficult to bear the fact that they are not able to find their job just because of their disease and health barriers resulting from it. Our participants encountered stigma in the workplace that makes the entry onto the workforce much more difficult, too. A negative image of people suffering from mental illness is deeply rooted in society and we can see it also in the job area. An opinion of Wenigová [13] just supports our findings that problems with getting and keeping a job are to a certain extent a consequence of stigmatization. All the above mentioned problems result in financial difficulties, these people are dependent on the help from their relatives and the state. This puts them to the margins of society. One of the participants even stated that financial limitations cause his lowered social contacts, which leads us to the next, third category. 
The third category deals with barriers in social interaction and it is the most extensive category in our paper. Problems stated within it, mentioned by our participants, are interrelated and depend on each other. The participants mention, e.g., the fear of prejudices which was the reason of their decision to keep the illness as a secret not just from the community, but also from the relatives. They got scared that if the people knew about their illness, they would see them as madmen, and they would underestimate them and perceive them to be deficient. One of participants stated that before he got ill he shared the same ideas, and now he is afraid that these prejudices are still present in society. This fact was a reason why he hesitated to look for the special assistance and undergo the treatment. Due to their fear, participants isolated themselves from the community and even broke contacts with their friends and acquaintances. Although they mention isolation also from their environment, they said that it was their inner fight that did not allow them to cross this barrier and get into contact with friends again. Participants mentioned broken contacts not just with friends but also with relatives. It was caused on one hand by the fear of prejudices and on the other hand it was a consequence of family conflicts because of the disease. Two of our participants experienced family conflicts caused also by rejecting the illness by the family members and their impossibility to accept this serious fact. Therefore in the beginning our participants were confronted with accusations and blaming in families. In our research we also analyzed stigmatization within social interaction - situations in which the participants were underestimated and discriminated. To the previous categories we included stigmatization and stigma at the workplace because in this case stigma was an employment barrier and it had financial impacts on their everyday life. All the mentioned facts led our participants into searching for a company of people with the same problem. They perceived them as people of the same "blood group" and with them they felt safe. These newly formed friendships are very important to them. They share experience and advice with each other, and this helps them to overcome the consequences of their illness. From the other point of view we can classify it as limitations of contacts just to a certain groups of people and its consequences are the above mentioned isolation and break of contacts with friends. Our research findings are confirmed by many authors in the theoretical part of our paper. Marková [8] claims that people exposed to stigmatization usually decide for change in social behaviour. They then limit the social contacts with the community, isolate themselves, communicate very prudently and search for a company of people with the same problem who would not judge them.

Wenigova [13] writes about other facts, established also by us in our thesis. These are: the rising isolation of people suffering from schizophrenia, which causes people following stigmatization to reject treatment in order not to be classified as mentally ill people. The greatness of the stigmatization and prejudices in society we can see in marking it as a "secondarily disease".

The fourth category is the emotional experience of the disease. Getting over schizophrenia is not easy. Participants are deeply affected by the illness. In our collected data we analyze, e.g., a feeling of shame and sense of inferiority of the participants. They mentioned feelings of shame associated with receiving a disability pension and their unemployment. One of the participants perceives sense of inferiority in meeting with his acquaintances based on the fact that he does not work. Based on these feelings, the participants tend to isolate themselves and keep the disease as a secret. This fact proves an argument that people suffering from a mental disease can get the sense of inferiority as a result of the lowered social status of a person. The way a person sees themselves is to some extent a reflection of the society's viewpoint. It is one of the next causes of isolation and social exclusion [14]. 


\section{Health Barriers}

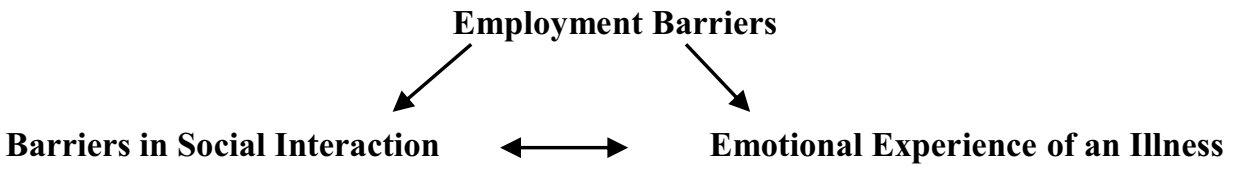

Figure 1. Visualising of the relationship between categories I.

Before the outbreak of a disease our participants lived a normal life. They were working, studying and living in a community. The outbreak of the disease and problems accompanying it are a major trauma for them. Therefore they are searching for a deeper sense of an illness. They try to look for the cause of it in faith. Despite all the mentioned difficulties and miseries that schizophrenia causes in life they do not lose the faith in recovery. They have their desires and goals. They would like to achieve them using medical treatment, psychotherapeutic assistance and a faith. They try to have an optimistic point of view. These people are constantly searching for new information that might be helpful for them in the healing process and integration into life. Into the category of emotional experience of an illness we included also the need to keep the illness as a secret within the family in order to protect them against suffering and sorrow. Based on their statements, they tried not to bother them with their own problems.

As we indicated at the beginning of the discussion, the categories identified by us are interrelated. Health barriers influence predominantly the patient's ability to work. As the participants' answers reveal, their illness had caused a complete aversion to work and the need to force them to everything. Work barriers influenced the patients' social interaction, as well. This can be confirmed by the participants' statements about the lack of money, which isolates them from their community and disclaim them from being in contact with people. Especially because of their inability to work and loss of their job, participants isolate themselves, keep their illness as a secret and do not get in touch with their family and friends. Work barriers affect also the emotional experience of the illness, since the participants feel shame and sense of inferiority because of being unemployed and receiving disability pension. Last, but not the least, emotional barriers influence their social interaction, as well. Our participants isolate themselves from the community because of feeling ashamed and inferior. Having limited contacts with their friends is being perceived as a problem in participants' statements, as well.

We noticed that for people suffering from schizophrenia, having a job is an important pillar of integration into the society. It is the most important for our participants to take part in creating the social values. It is the missing link that would enable them to feel useful again, not just for the society but also for themselves.

\section{Research results interpretation: Research sample No. 2}

Schizophrenia is a serious mental illness that affects not just the person suffering from it, but also his family members. Those are mainly people who had been living with him before the outbreak of an illness, as well as in the process of the patient's medication; and people who take care of him/her. From the participants' answers we have identified several problems that occur in their everyday life since the outbreak of an illness. We have divided them into four main categories: 
The first category deals with economic life barriers. From the participants' answers we found out that the illness of their mentally ill family member influenced mainly the economic part of their life. The lack of financial resources was marked as the most serious problem. The problem was caused by the fact that two of three participants had to stay at home and were working as caregivers, receiving just the caregiver's financial assistance. The lack of financial resources caused families to be more economical. Problems with money they perceived also when travelling to the hospital or to the daily care centre because of the high financial costs of transport. Our findings can be supported by Motlová [15] who claims that families often struggle with the lack of services for their mentally ill members in the place where they live. This is connected with a bigger financial costs and inability to earn extra money when being a caregiver. Financial problems are, as we mentioned, caused by the loss of job since there has to be a person who will, after the outbreak of the disease, take care of a mentally ill person. In families with a mentally ill member we observed the need of financial support from the other family members. One of our research participants, a sibling of a mentally ill person, needed to financially support her family by contributing to their family budget. All in all, financial problems of families with mentally ill people affect their life quality and can become an existential problem.

The second category deals with barriers in social interaction. The most significant impact of schizophrenia on a family member was in the field of their social interaction. Taking care of a person suffering from schizophrenia is accompanied by many considerable restrictions. The family is forced to adapt their life to its member's illness. Our research participants stated that an outbreak of schizophrenia was associated with limitations of their free time activities. Their free time became devoted predominantly to the ill person and to home care. The participants mentioned the loss of privacy and the loss of an ability to live their own life, as well. These problems were caused by the need to adjust their life to the member suffering from schizophrenia. Motlová [15] declares the same. She writes that the reduction in free-time activities in the family, taking care of its mentally ill member, is caused by the need to take care of him on one hand, and by the isolation of the family on the other hand. Family does not anymore focus on their own needs, but on their ill member's needs. In life of our research participants it causes the restrictions of social contacts. As they stated, the limitation of social contacts is not caused by stigmatization, but by both the lack of time to fulfil their needs and adjustment of their life to a mentally ill family member. However, family members did not escape from stigmatization. In dialogues they mentioned prejudices of people revealed by some inappropriate comments, questions or rise of distance. They experienced prejudices from people living in their neighbourhood, not from their friends. The research participants even lost an interest in contacts with their own friends. Speaking about this, we were able to observe a certain depression and "burnout" syndrome. One of the participants even mentioned that he was not able to listen to the others' problems because of the fact that he had to solve his own problem first. These restrictions can be related to their need of supervision - another problem expressed by our research participants. It is caused, on one hand, by the dependence (we have mentioned this problem in Interpretation of Results of a Research with Sample No. 1), that people suffering from schizophrenia deal with. On the other hand, it is caused by the fear of allowing a mentally ill person to be without any supervision. Since people suffering from schizophrenia often refuse the medication, family members have to provide supervision in medication. The above mentioned problems we perceive as significant barriers in interaction with community. Barriers in interaction were identified in relationship between family members and their mentally ill member, as well. This relationship is affected by the change in the view of an illness. After an outbreak of the illness the mentally ill person changes and family has to react to it. Family members give the 
ill person easier tasks to do, and try to relieve stress and all the things that might worsen the patient's state. The change in attitude is perceived by the participants also from their relatives and friends. In one of the participant's situation even a change in attitude towards the family member occurred. He, as a sibling, was so hurt by the patient's disease symptoms, that their relationship became influenced by that. On the other hand, parents of a mentally ill family member have not changed their attitude towards him and a strong emotional tie between them can still be observed. Taking care of a mentally the ill person and living with him brings various problems. For example, in participants' answers we identified an emotional blackmail by the mentally ill that can hurt and mentally destroy the family. There were also conflicts caused by the symptoms of the patients' illness and the family's inability to overcome them which result into quarrels.

The third category deals with the emotional load, i.e., the psychological stress that patient's illness causes to his family. Psychological stress in the family is also supported by the research of Ondrejka, Drímalová and Mažgútová [16], whose result shows that psychological comfort of parents having a child, suffering from schizophrenia, is often disturbed. When an illness sets in, family is not prepared for this situation. In the very beginning there is no idea what happens with their family member; the people are not able to see the symptoms. At this stage we can encounter the negotiation of an illness. This information was confirmed in the participants' answers, as well. In the beginning the family members were not able to get used to the fact that the person may be mentally ill. They rejected this fact until the moment when the diagnosis was confirmed by the experts. Our participants later experienced remorse. At this point people start to revaluate their process of illness identification which often comes with self-blaming. There is also fear about life of their beloved one. Fear comes from the participants' own experience, as well as from information given in scientific literature or in mass media. We talk here about the risk of suicide. One of the participants mentioned a situation, when the mentally ill person threatened to commit suicide; and that increased the family's fear about him. This situation usually causes the raise of supervision and deepening of isolation, as well as the complete loss of their private life. The analysed interviews revealed also the fear from future. Family worries about their mentally ill member, and about what will happen to him. There are also worries about worsening of the patient's health state. It is the fear of the unknown. Here the Dörner's [17] claim is very similar to our above mentioned findings. The author claims that a great amount of mentally ill patient's family members experience feelings of guilt and remorse. Sense of their failure is typical especially for parents of children suffering from schizophrenia. He also declares that this new situation evokes fear, worries, an overwhelming sense of powerlessness, and the fear of future.

The category of psychological stress includes also the feeling of compassion towards their family member. Based on that, people suppress their own needs in favour of the good and satisfactory life of their ill family member. They so much want him/her to be healthy, that they live with false hope. Especially in the beginning the family hopes that the patient's state will improve. Awareness of the opposite fact is then extremely painful. For family it is a painful, never-ending circle of ups and downs. Hospitalization has a negative impact on our research participants, too. The problems are caused by an effect of psychiatric department at hospitals or psychiatric hospitals into which their family members are sent at the outbreak of the acute phase of the disease. Analysing the interviews with the selected sample of the participants, we found out that, even after a long time period, family is not able to cope with the disease of its member. They perceive schizophrenia of their child or a sibling as very painful. They try to learn to live with it, but they are usually unable to cope with it. Probably this is the reason why our research participants need to share their problems with friends. The 
chance to talk about that represents a certain form of mental hygiene. According to one of our participants, it is not easy to talk about such a serious mental illness and problems that accompany it, and he sometimes feels ashamed of it. Nevertheless, the need to talk is much stronger, as he says. These findings are partially in contrary to the claims of Dörner [17], who declares that based on feelings of guilt family keeps their member's illness as a secret. In our interviews, this declaration was supported just partially. Our participants felt ashamed, but they did not keep it as a secret.

One of the research participants perceives the fact that the illness cannot be cured as extremely difficult. Participants, who quit their job and take care of their children, mentioned also that they need to be very supportive. As stated in their answers, they have to be mentally and emotionally strong to support their children.

The fourth category is the structural discrimination. The first problem is the lack of care centres. The participants would appreciate more care centres in smaller towns, so that they would not be required to travel long distances when attending it. Travelling is not just timeconsuming, but also a money-consuming matter. Care centres that would not be far from the patient's homes would give them time for rest, private space and it would also help the patients whose health state might improve due to the therapy, consultations and care centre attendance. It should have a positive impact on an overall functioning of the patient suffering from schizophrenia, as well as on his family members. At present there are just 19 daily care centres in Slovakia [18]. It is not much, considering the fact that almost $1 \%$ of population suffers from schizophrenia [3].

The lack of information was the next problem, experienced especially at the initial stage of the illness, as revealed by our research participants. Based on this, we analyzed an unawareness that caused denial of the illness and postponing of the visit to a specialist, as well as new medication initiation. Especially due to the lack of general knowledge, the family members were forced to look up information on the illness in various scientific publications, magazine articles, media and in the internet. Our participants have faced the society's lack of knowledge of the illness (among their friends and relatives) and had to inform them about this serious fact of a mental illness. Lack of information was, according to them, caused by barriers in contacts with the doctors, too. Doctors did not have enough time to give the family detailed information on the illness. Doctors did not provide family members with information about problems that they may be required to solve, or they used so much scientific vocabulary that people had no chance to grasp the meaning. The structural elimination contains also problems in official communication that one participant experienced. He perceived the regular controls and assessment of dependency as restrictive.

Based on these categories we can identify many problems that bother family members of a mentally ill person suffering from schizophrenia. These facts are approved by the words of Motlová [15], too. She divides the impact on the family into the objective and subjective burden. The objective burden represents the direct care and its impact on different aspects of the family life, its impact on other family members, free-time activities, job, mental and body health, social network, everyday family habits and financial impact. Subjective burden is represented by an individual reaction of a care provider. All these problems, as we can see in interpretation of the research results, we found in explanations of our participants, as well.

Individual categories and problems incorporated in them are interrelated. The most significant relationship that we analysed was the one between the barriers in social interaction and psychological stress. For example, feelings of guilt lead family members into the loss of privacy and social contacts restrictions. Family does not endure if their member has no friends to spend free time with and therefore they sacrifice their own free time in favour of the mentally ill person. Also threatening, conflicts and the necessity of change of an attitude lead 


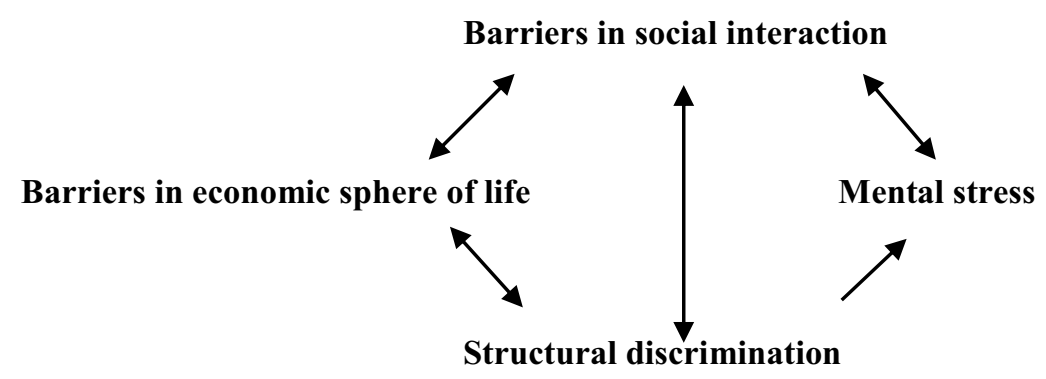

Figure 2. Visualising of the relationship between categories II.

to an inability to cope with the illness. Prejudices in company cause the sense of guilt. These two categories are deeply interrelated. However, we cannot claim that there is no relationship between the other detected categories. Barriers in economical life are related to the structural discrimination and that has an impact on the barriers in social interaction. It can be supported by the participants' statement that the lack of financial resources influences the chance to ensure an increased care in the form of visits to daily care centres, which results into the need of care provision by their family. Lack of information at the beginning of the disease outbreak often results into its denial. That is the relationship between structural discrimination and psychological stress of a family.

A quality of care for people suffering from schizophrenia is constantly increasing. However, the family of a mentally ill person remains at the margins of the attention from the state, society and professional public, too. Therefore, an impact of the illness is so great and significant. Even if there is a certain form of help, they either have no information about it or would have to travel long distance in order to make use of their services. That is almost impossible when they need to care of a mentally ill person. All this creates problems that family has to solve on their own.

This paper was prepared as a part of the project The Identity of Social Work in the Context of Slovakia [APVV-] funded by the Slovak Research and Development Agency.

\section{References}

[1] E. Malá, P. Pavlovský. Psychiatrie., 144 p. ISBN 80-7178-700-0 (Praha: PORTÁL 2002).

[2] Objavte cestu ako íst' d'alej. 98 p. ISBN 80-88952-31-X. (Trenčín: F, 2006).

[3] Čo je schizofrénia. [online]. Dostupné na: <http://www.dusevnezdravie.sk/ schizofrenia.html>

[4] D. Hell, D. Schüpbacha. Schizofrénie. 159 p. ISBN 80-88952-19-0. (Trenčín: F, 2004).

[5] Breier In: K. Bánska,. Vykročme z hmly- proti predsudkom spoločnosti. Zdravotnícke noviny. ISSN 1335 4477, 2006, roč. 11, 14, 39 (2006).

[6] E. Češková. Léčba schizofrenie. Psychiatrie pro praxi. [online]. 2009, roč. 10, 6, p.265-269[. Dostupné na: <http://www.solen.sk/index.Php?page=pdf_view \&pdf_id=4176\&magazine_id=2 > (2009).

[7] M. Ondriášová. Psychiatria. 117 p. ISBN 80-8063-199-9 (Martin, OSVETA, 2005). 
[8] O. Matoušek In. E. Marková, M. Venglářová M. Babiaková. Psychiatrická ošetřovatelská péče. 352 p. ISBN 80-247-1151-6. (Praha, GRADA PUBLISHING 2006).

[9] J. Levická. Sociálna diagnóza - jej premeny v čase. In: Posouzení životní situace v sociální práci. ISBN 978-80-7041-419-4 (Hradec Králové : Gaudeamus 2008).

[10] K. Levická. Riziká diagnózy v sociálnej práci. In: Posouzení životní situace v sociální práci. ISBN 978-80-7041-419-4 (Hradec Králové : Gaudeamus 2008).

[11] R. Práznovská, O schizofrénii a chorých na schizofréniu. Podpora zdravia. ISSN 13353179, 2001, roč. 5, 2, p. 4-6 (2001).

[12] I. Dóci. Sociálne problémy pacientov so schizofréniou. Psychiatria. ISSN 1335-423X, roč. 10, č.1, s 6-9 (2003).

[13] B. Wenigová, Stigma a psychiatrie. [online]. Dostupné na: <http://www . stopstigmapsychiatrie.cz/stigma-psychiatrie-napric-casem-wenigova . html>

[14] K. Repková, L. Požár, L. Šoltés, Zdravotné postihnutie v kontexte novodobej sociálnej politiky., 214 p. ISBN 80-89141-03-X (Bratislava, INFORMAČNÁ KANCELÁRIA RADY EURÓPY 2003).

[15] L. Motlová. Schizofrenie a rodina: Mapování názorů, postojů a prožitků příbuzných jako základ rodinných intervencí. Psychiatrie. ISSN 1211-7579, 2005, roč. 9, č. 3, p.100-104 (2005).

[16] I. Ondrejka, M. Drímolová, A. Mažgútová . Vplyv psychotickej poruchy diet'at'a na kvalitu života rodiny. Česko - slovenská pediatrie. ISSN 0069-2328, roč. 58, č. 2 , p. 66-69 (2003).

[17] K.Dörner. Osvobozující rozhovor. Psychicky nemocný v rodine. 132 p. ISBN 80-7169892-X. (Praha: GRADA PUBLISHING 1999).

[18] Daily Care Centres in Slovakia. Denné psychiatrické stacionáre v SR. [online]. [cit. 2014-01-30]. Dostupné na internete: <http://www.odos-sk.com/download/ Adresar_uzitocnych_kontaktov.pdf $>$ 